\title{
The Effects of Windthrow Damage on Soil Properties in Scots Pine, Black Pine and Kazdağı Fir Stands in the Northwest \\ Turkey
}

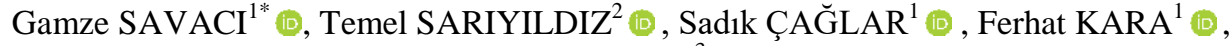 \\ Esra TOPAL $^{3}$ (D) \\ ${ }^{1}$ Kastamonu University, Faculty of Forestry, Kastamonu, TURKEY \\ ${ }^{2}$ Bursa Technical University, Faculty of Forestry, Bursa, TURKEY \\ ${ }^{3}$ Milas Forest Enterprise Directorate, Kayadere Forest Sub-district Directorate, Muğla, TURKEY \\ *Corresponding Author: gsavaci@kastamonu.edu.tr
}

\section{Abstract}

Aim of study: The short-term effects of windthrow damage on soil properties were investigated in Kazdağı fir (Abies nordmanniana subsp. equi-trojani), Scots pine (Pinus sylvestris L.) and black pine (Pinus nigra Arnold.) stand in northwest Turkey.

Area of study: The study was carried out in Kastamonu and Sinop regions.

Material and methods: In order to understand the effects of windthrow damage occurred in 2013, soil samples were collected at a depth of 0-30 cm from the disturbed and undisturbed sites in 2018 (5 year later), and analyzed for soil physical and chemical properties.

Main results: The increases in temperature, wind speed and heavy rainfall in the study sites seemed to result in the windthrows. There were significant differences in soil physical and chemical properties among the three tree species, and also between the disturbed and the undisturbed sites.

Highlights: After the windthrows, increased SOC and TN stocks, P and K could be related to the accumulation of organic matter. However, we were not able to identify a single mechanism to explain this observed relationship. Thus, the root-soil interactions of the three tree species should be conclusively examined in future studies in order to define the relationships between soil chemical properties and root features.

Keywords: Windthrow Damage, Soil Properties, Microclimate, Tree Species, Carbon Stock

\section{Türkiye'nin Kuzeybatısında Yetişen Sarıçam, Karaçam ve}

\section{Kazdağı Göknar Meşcerelerinde Rüzgâr Devrik Zararının Toprak Özelliklerine Etkileri}

Öz

Çalışmanın Amacı: Türkiye'nin kuzeybatısı Kazdağı göknarı (Abies nordmanniana subsp. equitrojani), sarıçam (Pinus sylvestris L.) ve karaçam (Pinus nigra Arnold.) meşcerelerinde rüzgâr devriği zararının toprak özelliklerine kısa vadeli etkileri ortaya konmaya çalışılmıştır.

Çalışma alant: Çalışma Kastamonu ve Sinop bölgelerinde gerçekleştirilmiştir.

Materyal ve yöntem: 2013 yılında meydana gelen rüzgâr devriğinin etkilerini anlamak için, devrik görülen ve görülmeyen alanların 0-30 cm derinlik kademesinden toprak örnekleri 2018 yılında (5 yil sonra) alınmış ve bazı fiziksel ve kimyasal özellikleri belirlenmiştir.

Temel Sonuçlar: Çalışma alanında sıcaklık, yağış ve rüzgâr hızındaki artışın rüzgâr devriği zararına neden olduğu değerlenmiştir. Toprağın fiziksel ve kimyasal özellikleri üç farklı ağaç türü ve aynı zamanda rüzgâr devriği görülen ve görülmeyen alanlar arasında önemli derecede farklılıklar göstermiştir.

Araştırma vurguları: Rüzgâr devriğinden sonra; TOK ve TA stokları, P ve K artışı organik madde birikimi ile ilişkili olabilir. Bununla beraber, bu ilişkiyi açıklamak için tek bir mekanizma belirleyemedik. $\mathrm{Bu}$ nedenle, toprağın kimyasal özellikleri ile kök özellikleri arasındaki ilişkileri tanımlamak için, üç ağaç türünün kök-toprak etkileşimlerinin ileriki çalışmalarda detaylı olarak incelenmesi gerekmektedir.

Anahtar Kelimeler: Rüzgâr Devrik Zararı, Toprak Özellikleri, Mikroiklim, Ağaç türü, Karbon Stoku 


\section{Introduction}

Forests are a natural part of many ecosystems on earth, including mountainous regions, and the structure of these ecosystems can be disturbed as a result of natural or anthropogenic interventions (Hartmann et al., 2016; Mina et al., 2017; Gáfriková et al., 2020). As a result, all terrestrial ecosystems can become more vulnerable due to changes in natural and environmental conditions with increasing global climate change (Sommerfeld et al., 2018). Windthrows, more common of these disturbances, can cause great damage to individual trees, small tree groups or severe damage to many hectares of trees (Gömöryová et al., 2008). After these disturbances, the environment, especially the microclimatic conditions, often changes such as solar radiation, precipitation, heat input to the soil surface, and intense air circulation, can be observed (Gömöryová et al., 2008). Severe winds cause complete loss of tree canopy and soil degradation (Stephens, 1956; Schaetzl et al., 1989).

Many studies have examined the effects of windthrow damage on timber yields, wildlife, insect damage, soil properties, etc (Quine, 1995a; von Oheimb et al., 2007; Mason \& Valinger, 2013). Windthrow damage is quite a threat to forest production because it adversely affects timber yields, site quality and wildlife (Quine, 1995a). The economic impact is particularly severe in rapidly growing semi-mature forests. Wind disturbances reduce timber yield and increase the cost of extraordinary thinnings in stands resulting in disruptions in planned forestry management.

The risk of windthrow in a forest is mainly affected by climate, topography and region where the forest is formed (Mason \& Valinger, 2013). In these circumstances, stand and soil properties (e.g., tree species, soil type, stand management) serve to define the critical wind velocity at which damage will form (Lohmander \& Helles, 1987; Solantie, 1994), whereas local wind extremes, climate and topography as a whole determine how probable such a wind speed will be (Quine, 1995b). The intensity and therefore the severity of wind-induced damage is shown to be highly dependent on the maximum sustained wind speed and the duration of the wind exposure (Gardiner et al., 2010). Windthrow in northern Europe and especially extensive windthrows is often caused by winter storms generating high wind speeds of more than $30 \mathrm{~m} \mathrm{~s}^{-1}$ (Riguelle, 2016). In addition, windthrow gaps formed as a result of the uprooting of trees cause different soil disturbances (von Oheimb et al., 2007). That is, mineral soil is exposed in the uprooted mounds, and the physical properties of the soil change. Compared to the undisturbed forest floor, mounds are exposed to a higher amount of light. Soil temperature is higher and soil moisture is lower where the uprooting occurs (Beatty \& Stone, 1986). Soil dynamics can be especially affected by the uprooting and accumulation of organic matter and subsoil materials in the mineral topsoil. The available soil water may increase in gaps due to reduced transpiration of canopy trees in wet soils (Bouget \& Duelli, 2004). In some cases, windthrows that are effective in reaching and mixing mineral and organic soil horizon down to bedrock can also affect the amount of soil organic carbon (Kramer et al., 2001). Klaus et al. (2011) reported that poor soils with high erodibility and large grain size were more sensitive to windthrow.

Windthrows represent large-scale and dominant natural disturbances in Northern and Central Europe. The damaged forests by windthrows consist mainly of Douglas fir (Pseudotsuga menziesii (Mirb.) Franco), beech (Fagus spp.), silver fir (Abies alba Mill.), Scots pine (Pinus sylvestris L.), oak (Quercus spp.) and Norway spruce (Picea abies L.) (Majunke, 2008; Gardiner et al., 2010). Over $26.5 \mathrm{Mm}^{3}$ in Germany, Austria, Switzerland, Czech Republic and France in 1967 were reported following the windthrow disturbances (Gardiner et al., 2010). The storms that occurred in 1999 also caused widespread damage, especially in Denmark, France, Germany, Austria and Switzerland. There were $180 \mathrm{Mm}^{3}$ of windthrow damages in those countries (Pischedda, 2004). In 2009, 43.1 $\mathrm{Mm}^{3}$ of wind damage was reported in France and northern Spain. Oak and maritime pine (Pinus pinaster Ait.) in France, radiata pine (Pinus radiata D. Don) 
and Eucalyptus globulus in Spain were damaged (Gardiner et al., 2010).

A total of $5.5 \mathrm{Mm}^{3}$ windthrow damage has occurred in the northwestern part of Turkey for the last twenty years (Engür, 2010; 2014). Although the windthrow disturbances to Turkish forests have been increasing through time, to our knowledge, the studies on the effects of the windthrow damage on soil properties are limited to Turkish forest ecosystems. Therefore, in this present study, we aimed to (1) characterize the effects of windthrow disturbances on soil physical and chemical properties in Scots pine (Pinus sylvestris L.), Kazdağ 1 fir (Abies nordmanniana subsp. equi-trojani) and black pine (Pinus nigra Arnold.) stands, (2) to define the effects of tree species and windthrow on soil properties. Scots pine, Kazdağ 1 fir and black pine are economically and ecologically very important tree species in Turkey. The results in this study would create a basis for our knowledge to better understand the windthrows-soil properties relationships within the stands of the selected trees.

\section{Material and Methods}

Description of the Study Sites and Sampling

On 15 March 2013, a strong storm and wind seriously uprooted approximately 1.5 $\mathrm{Mm}^{3}$ trees in Kastamonu and Sinop regions, in northwest Turkey (Engür, 2014). The damaged stands were located in Tekçam and Bayam forests in Kastamonu, and Sakız and Suludüz forests in Sinop. The Tekçam and Bayam sites were $44 \mathrm{~km}$ away from Kastamonu, while the Sakız and Suludüz sites were $84 \mathrm{~km}$ and $37 \mathrm{~km}$ away from Sinop. Silvicultural characteristics of the stands, forest road conditions and soil properties were studied in the four windthrow disturbed sites (i.e., Tekçam, Bayam, Sakız and Suludüz) (Figure 1).

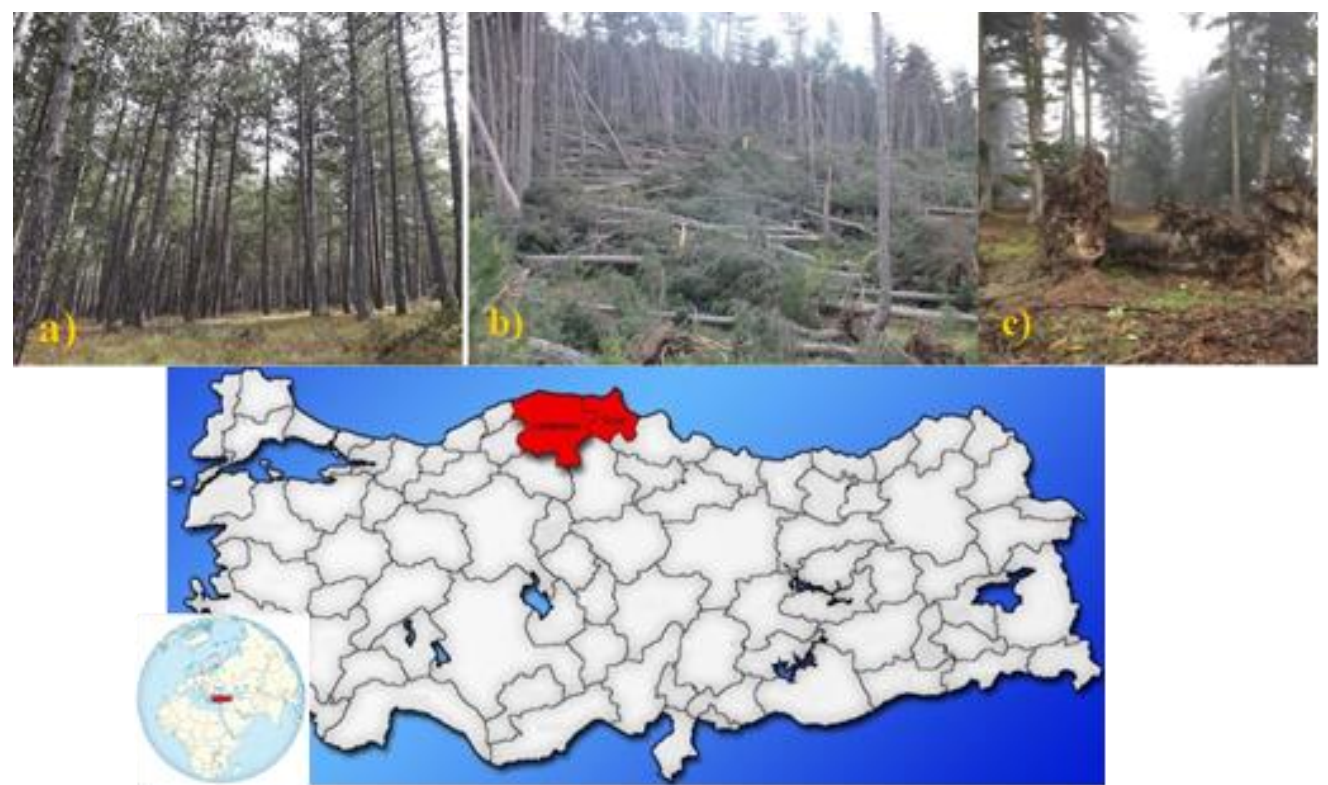

Figure 1. The locations of the study areas, the black pine control site (a) and the windthrow damaged sites of black pine (b) and fir (c)

Main characteristic of the forest stands, soil and skidding roads in the study sites are given in Table 1. The four study sites generally show warm and temperate climate types. Mean annual temperature was $12.9^{\circ} \mathrm{C}$ and total annual precipitation was $643 \mathrm{~mm}$ in these sites. The altitudes of the studied sites varied from $1170 \mathrm{~m}$ to $1300 \mathrm{~m}$ a.s.l., and the sites were located on the south aspect.
Average slope was between $10 \%$ and $15 \%$. According to the geological map (1:1.250.0000 scale), the four study sites had different geological rock types. Those were neritic limestone rocks in Sakız, komatiite rocks in Bayam, schist rocks in Tekçam and flysch rocks in Suludüz (Akbaş et al., 2011). Soil type was a Rendzic Leptosol type for all four sites according to the European Soil 
Bureau Network (ESBN, 2005). Leptosols are mostly shallow over hard rock and comprise of very gravelly or highly calcareous material (ESBN, 2005).

Table 1. Description of the studied sites

\begin{tabular}{|c|c|c|c|c|}
\hline \multirow{2}{*}{$\begin{array}{c}\text { Study region } \\
\text { Study site }\end{array}$} & \multicolumn{2}{|c|}{ Kastamonu } & \multicolumn{2}{|l|}{ Sinop } \\
\hline & Bayam & Tekçam & Sak1z & Suludüz \\
\hline Number of subplots & 11 & 17 & 7 & 11 \\
\hline Latitude & $41^{\circ} 23^{\prime} 02^{\prime \prime} \mathrm{N}$ & $41^{\circ} 31^{\prime} 44^{\prime \prime} \mathrm{N}$ & $41^{\circ} 38^{\prime} 51^{\prime \prime} \mathrm{N}$ & $41^{\circ} 41^{\prime} 27^{\prime \prime} \mathrm{N}$ \\
\hline Longitude & $34^{\circ} 22^{\prime} 46^{\prime \prime} \mathrm{E}$ & $34^{\circ} 21^{\prime} 07^{\prime \prime} \mathrm{E}$ & $34^{\circ} 50^{\prime} 10^{\prime \prime} \mathrm{E}$ & $34^{\circ} 58^{\prime} 10^{\prime \prime} \mathrm{E}$ \\
\hline Aspect & Southwest & South & South & South \\
\hline Size of study sites (ha) & 68.40 & 97 & 16.8 & 18.2 \\
\hline Altitude $(\mathrm{m})$ & 1200 & 1170 & 1300 & 1300 \\
\hline Slope (\%) & 10 & 15 & 10 & 10 \\
\hline Bedrock type & $\begin{array}{c}\text { Komatiite } \\
\text { Metaultrabasic }\end{array}$ & $\begin{array}{l}\text { Schist from the } \\
\text { Triassic-Lower } \\
\text { Jurassic period }\end{array}$ & $\begin{array}{l}\text { Neritic limestone from } \\
\text { the Middle Jurassic- } \\
\text { Cretaceous period }\end{array}$ & $\begin{array}{c}\text { Flysch from } \\
\text { the Upper } \\
\text { Senonian period }\end{array}$ \\
\hline Soil type & $\begin{array}{l}\text { Rendzic } \\
\text { Leptosol }\end{array}$ & $\begin{array}{c}\text { Rendzic } \\
\text { Leptosol } \\
\end{array}$ & $\begin{array}{l}\text { Rendzic } \\
\text { Leptosol }\end{array}$ & $\begin{array}{c}\text { Rendzic } \\
\text { Leptosol }\end{array}$ \\
\hline Total soil samples & 33 & 51 & 19 & 33 \\
\hline Year of windthrow damage & 2013 year & 2013 year & 2013 year & 2013 year \\
\hline Tree species & $\begin{array}{l}\text { Scots pine } \\
\text { Black pine }\end{array}$ & Black pine & Fir, Scots pine & Fir, Scots pine \\
\hline Mean stand height (m) & 16.1 & 15.4 & 18.5 & 19.5 \\
\hline Mean stand age (years) & 77 & 56 & 60 & 84 \\
\hline Stand density $(\%)$ & 80 & 80 & 80 & 80 \\
\hline Production $\left(\mathrm{m}^{3}\right)$ & 1000 & 1700 & 3775 & 396 \\
\hline Extraction vehicle & $\begin{array}{l}\text { Agricultural } \\
\text { tractor }\end{array}$ & $\begin{array}{l}\text { Agricultural } \\
\text { tractor }\end{array}$ & $\begin{array}{l}\text { Agricultural } \\
\text { tractor }\end{array}$ & $\begin{array}{l}\text { Agricultural } \\
\text { tractor }\end{array}$ \\
\hline Forest road type & Stabilized road & Soil road & Asphalt road & Asphalt road \\
\hline $\begin{array}{l}\text { Forest path longitudinal } \\
\text { slope }(\%)\end{array}$ & $2 \%-3 \%$ & $8 \%-13 \%$ & $2 \%-5 \%$ & $3 \%-5 \%$ \\
\hline Maximum slope $(\%)$ & $3 \%$ & $10 \%$ & $2 \%-5 \%$ & $5 \%$ \\
\hline Minimum slope $(\%)$ & $0-1 \%$ & $6 \%$ & $2 \%-3 \%$ & $3 \%$ \\
\hline $\operatorname{Ditch}(\mathrm{m})$ & & & & \\
\hline 1) Initial & $1 \mathrm{~m}$ & $2.1 \mathrm{~m}$ & $1-2 \mathrm{~m}$ & $1 \mathrm{~m}$ \\
\hline 2) Middle & $1 \mathrm{~m}$ & $1 \mathrm{~m}$ & $2-3 \mathrm{~m}$ & $2 \mathrm{~m}$ \\
\hline 3) End & $1 \mathrm{~m}$ & $1.5 \mathrm{~m}$ & $1-2 \mathrm{~m}$ & $2 \mathrm{~m}$ \\
\hline $\begin{array}{l}\text { Embankment slope length } \\
(\mathrm{m})\end{array}$ & & & & \\
\hline 1) Initial & $0.8 \mathrm{~m}$ & $2.5 \mathrm{~m}$ & $2-3 \mathrm{~m}$ & $2-3 \mathrm{~m}$ \\
\hline 2) Middle & $2 \mathrm{~m}$ & - & $1-2 \mathrm{~m}$ & $1-2 \mathrm{~m}$ \\
\hline 3) End & $1.5 \mathrm{~m}$ & $1 \mathrm{~m}$ & $2-3 \mathrm{~m}$ & $2-3 \mathrm{~m}$ \\
\hline $\begin{array}{c}\text { The number of curves } \\
\text { (units) }\end{array}$ & $>20$ & 1 & 2 & 2 \\
\hline $\begin{array}{l}\text { Maximum curved width } \\
(\mathrm{m})\end{array}$ & 7 & 6 & $5-10$ & $5-10$ \\
\hline
\end{tabular}

In the Kastamonu region, tree species mostly affected by the windthrow damage were Scots pine and black pine trees, while Kazdağ 1 fir was mainly affected in the Sinop region. Mean stand density was $80 \%$ in undisturbed (control) stands. The forest path slope of the stands ranged from $2 \%$ to $13 \%$.
The maximum slope of the stands was $10 \%$ (Table 1).

In order to understand the effects of silvicultural characterics on the risk of windthrow, the uprooting was examined in the totally destroyed and partly damaged Scots pine, black pine and Kazdağ fir stands. Main characteristics of the stands (tree 
height, tree diameter and canopy closure) were measured in fifteen subplots (3 tree species $\mathrm{x} 5$ subplots $=15$ subplots) in each control site $\left(20 \mathrm{~m} \times 20 \mathrm{~m}=400 \mathrm{~m}^{2}\right)$. The control sites refered to the stands that were adjacent to the damaged areas at the four study sites. Measurements of diameter at breast height (DBH) at 1.3 meters of all trees were conducted using a diameter tape within the subplots. Trees within the subplots were cored at breast height to determine tree ages using the dendrochronological approach. The mean age of the control stands was highly diversified ranging from 56 to 84 years by using increment auger. The mean diameter of the control stands was ranged from $12.1 \mathrm{~cm}$ to $62.3 \mathrm{~cm}$. The height of trees within the plots was also measured by a Blume-Leiss clinometer. The mean height of the control stands was highly diversified ranged from 15.4 to $19.5 \mathrm{~m}$.

Moreover, Bosh GLM 80 marked laser distance meter was used to measure the lengths and slopes of forest road excavation and fill slopes. Different road types were available in the study sites (Table 1). The length of the skidding roads varied between $350 \mathrm{~m}$ and $2 \mathrm{~km}$, and their widths were between 3.5 and $5 \mathrm{~m}$. The longitudinal slopes of the skidding roads ranged from 15 to $20 \%$. The length of forest roads varied between $300 \mathrm{~m}$ and $1 \mathrm{~km}$ in the study sites, while the road width was between $5 \mathrm{~m}$ and $10 \mathrm{~m}$. A ditch of the roads was between $1 \mathrm{~m}$ and $3 \mathrm{~m}$.

Soil samples were taken from the control and windthrow stands of Scots pine, Kazdağ 1 fir and black pine. Total 46 subplots $(20 \mathrm{~m} \times$ $20 \mathrm{~m}$ ) were chosen for each site and a total of 138 soil samples were collected at the depth of $0-30 \mathrm{~cm}$ in October 2018. Undisturbed mineral soils were taken from $0-10 \mathrm{~cm}, 10-$ $20 \mathrm{~cm}$, and 20-30 $\mathrm{cm}$ soil depths using a soil cylinder with a diameter of $8 \mathrm{~cm}$ and a height of $10 \mathrm{~cm}$. The disturbed soil samples were also taken from a depth of between 0 and 30 $\mathrm{cm}$ to analyze soil texture. The soil samples were passed through a $2 \mathrm{~mm}$ sieve to remove stones and gravel for soil analysis.

\section{Soil Analysis}

Soil $\mathrm{pH}\left(\mathrm{H}_{2} \mathrm{O}\right)$ was measured in a 1:2.5 mixture of deionized water using a glass calomel electrode (LaMotte $\mathrm{pH}$ meter 5 series) after equilibration for $1 \mathrm{~h}$ in solution (Jackson, 1962). Bulk density was determined by weight loss after drying the undisturbed soil cylinders (Blake \& Hartge, 1986). The oven-dry weight of soil samples was sorted, ground in a mortar (without crushing stones), and fine soil $(<2 \mathrm{~mm})$, root, and skeletal part ( $>2 \mathrm{~mm}$ ) were separated by sifting through a $2 \mathrm{~mm}$ sieve (Karaöz, 1989). The bulk density samples saturated with water were subjected to free drainage (approximately 30 minutes) and weighed. Then, it was dried in an oven for $24 \mathrm{~h}$ at 105 ${ }^{\circ} \mathrm{C}$ and weighed. The maximum water holding capacity was calculated from the difference between these two weights as a weight percentage (Özyuvac1, 1975). Soil texture was determined using the hydrometer method of Bouyoucos (1962). Soil moisture content was calculated by weight loss after drying approximately $10 \mathrm{~g}$ of soil for $24 \mathrm{~h}$ at $105^{\circ} \mathrm{C}$ (Allen, 1989). Soil organic carbon and total nitrogen contents were measured using a CNH-S elementary analyser (Eurovector EA 3000 V.3.0 single, Milano-Italy) according to the dry combustion method. Nutrient concentrations $(\mathrm{Ca}, \mathrm{Mg}, \mathrm{P}, \mathrm{K}, \mathrm{S}, \mathrm{Al})$ in the soil samples were analysed using an energy dispersive X-ray Fluorescence Spectrometer (EDXRF Xepos II from Spectro -Analytical Instruments $\mathrm{GmbH}$ Boschstrasse- Kleve, Germany). Certified soil reference material (NIST SRM 2709) was used to assess the accuracy of the EDXRF analyses. The soil organic carbon (SOC) and total nitrogen (TN) stocks were calculated by multiplying soil mass, soil bulk density, and SOC or TN content and expressed as $\mathrm{Mg} \mathrm{ha}^{-1}$ (Lee et al., 2009; Sariyildiz et al., 2015). Soil mass was calculated as follows (eqn. 1):

$$
\mathrm{M}_{i}=\mathrm{BD}_{i} * \mathrm{~T}_{i} * 10^{4}
$$

where $\mathrm{M}_{i}$ is dry soil mass $\left(\mathrm{Mg} \mathrm{ha}^{-1}\right), \mathrm{BD}_{i}$ is bulk density $\left(\mathrm{Mg} \mathrm{m}^{-3}\right), \mathrm{T}_{i}$ is the thickness of the $i$-th soil layer $(\mathrm{m})$, and $10^{4}$ is the unit conversion factor $\left(\mathrm{m}^{2} \mathrm{ha}^{-1}\right)$. The fixed depth (FD) determination of areal SOC or TN stock is calculated as follows (eqn. 2): ])* $\mathbf{M}_{i}$ 
where $\mathrm{SOC}_{i-\text { fixed }}$ is the $\mathrm{C}$ (or $\mathrm{TN}_{i-\text { fixed }}$ is the $\mathrm{N}$ ) mass to a fixed depth ( $\mathrm{Mg} \mathrm{C} \mathrm{ha}^{-1}$ or $\mathrm{Mg} \mathrm{N}$ $\left.\mathrm{ha}^{-1}\right)$ and $\left[\mathrm{SOC}_{i}\right]$ or $\left[\mathrm{TN}_{i}\right]$ is the $\mathrm{C}$ or $\mathrm{N}$ content $\left(\mathrm{Mg} \mathrm{C}^{-1} \mathrm{a}^{-1}\right.$ or $\left.\mathrm{Mg} \mathrm{N} \mathrm{ha}{ }^{-1}\right)$ (Sariyildiz et al., 2015).

\section{Data Analysis}

Anemometry data from synoptic stations of Taşköprü, Boyabat and Gerze located near Sinop and Kastamonu were collected from 2013 to 2019. Microsoft Excel software was used to create Wind Rose Graphics (Kastamonu \& Sinop Meteorological Data 2013-2019).

Normality test calculated using the Kolmogorov-Smirnov and Levene tests were used to investigate the equality of the variances. Differences in soil properties between the windthrow status and tree species were tested by two-way analysis (ANOVA) using the windthrow status and tree species as independent factors. Interactions between the windthrow status, soil depths and tree species were also evaluated. Duncan's test was used to compare the average of the dependent variables that were significantly affected by the status. The relationships between the silvicultural characteristics and soil properties were assessed using Pearson Correlation.
Significant differences among the treatments were tested at $\mathrm{P} \leq 0.05$. The IBM SPSS v. 22 Software was used for all statistical analyses.

\section{Results \\ Annual Wind Roses for the Studied Sites}

Annual wind rose in the Sakiz site showed that air circulation was generally calm $(41 \%)$ compared to total annual monitored hours. The highest wind frequency was from the west and the second-highest wind frequency was from the southwest (22\%). According to the wind category frequency distribution chart for the Sak1z site, the highest wind speed was $12-18 \mathrm{~m} \mathrm{~s}^{-1}$ and $35 \%$ of overall wind was within the $225^{\circ}-270^{\circ}$ ranges (Fig. 2a). In the Suludüz site, with $22-29 \mathrm{~m} \mathrm{~s}^{-1}$ and $29-36 \mathrm{~m} \mathrm{~s}^{-1}$ the west winds had the highest speed (32\% of overall winds), and the winds from the southwest $(29 \%$ of overall winds) were within the $225^{\circ}-270^{\circ}$ ranges (Fig. $2 b$ ). In the Tekçam and Bayam sites, annual wind rose showed that the air circulation was calm (49\%) compared to total annual monitored hours. The southwest winds showed the highest speed, followed by the south. The highest wind speed was $25-33 \mathrm{~m} \mathrm{~s}^{-1}$, and $31 \%$ of overall wind was within $180^{\circ}-225^{\circ}$ (Figure 2c).

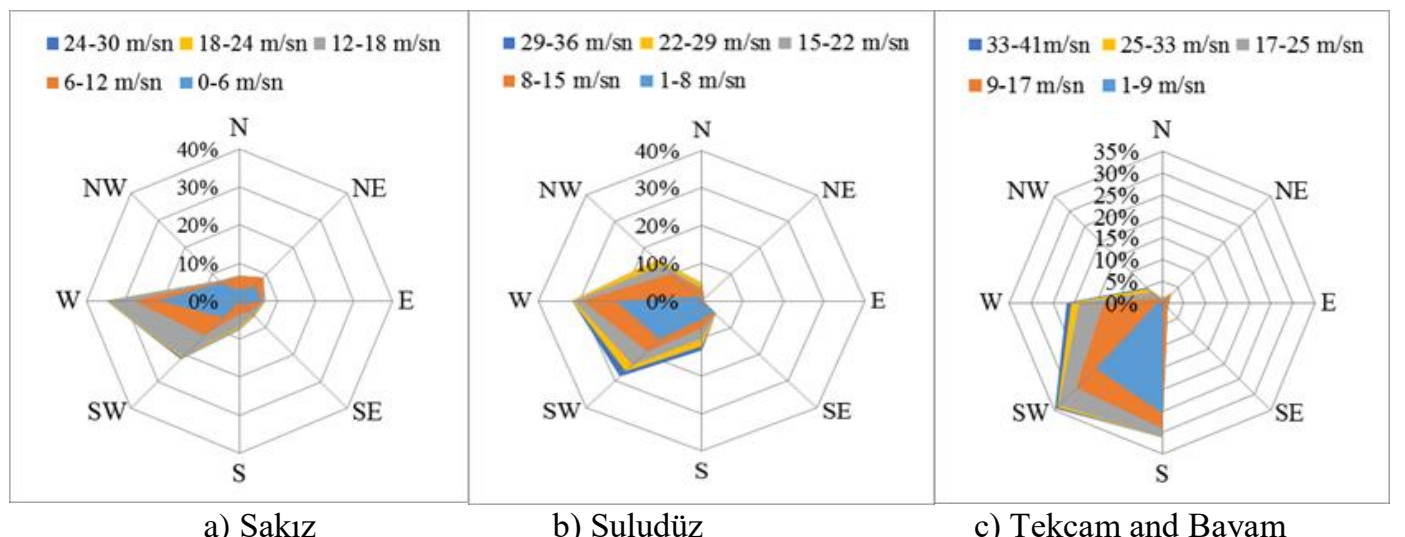

Figure 2. Wind rose plots show wind directions ( ${ }^{\circ}$ ) and wind speeds of the Sak1z (a) Suludüz (b) and Tekçam and Bayam (c) sites (data between 2013 and 2019 in Turkey)

\section{Uprooted Trees}

We noted that total 41429 trees were damaged by windthrow across the study sites. It was seen that black pine trees with a diameter of 8-18 $\mathrm{cm}$ and Scots pine trees with diameters of 20-34 cm were mostly uprooted by the windthrow. However, fir trees were less affected by the windthrow damage in all diameter classes across the study sites (Figure 3a). In the non-damaged (the control) sites, 51 Kazdagi fir trees with the diameter class of $36 \mathrm{~cm}$ to $50 \mathrm{~cm}$, and 39 Scots pine and 54 black pine with the 
diameter class of $20 \mathrm{~cm}$ to $34 \mathrm{~cm}$ were determined in this study (Figure 3b).

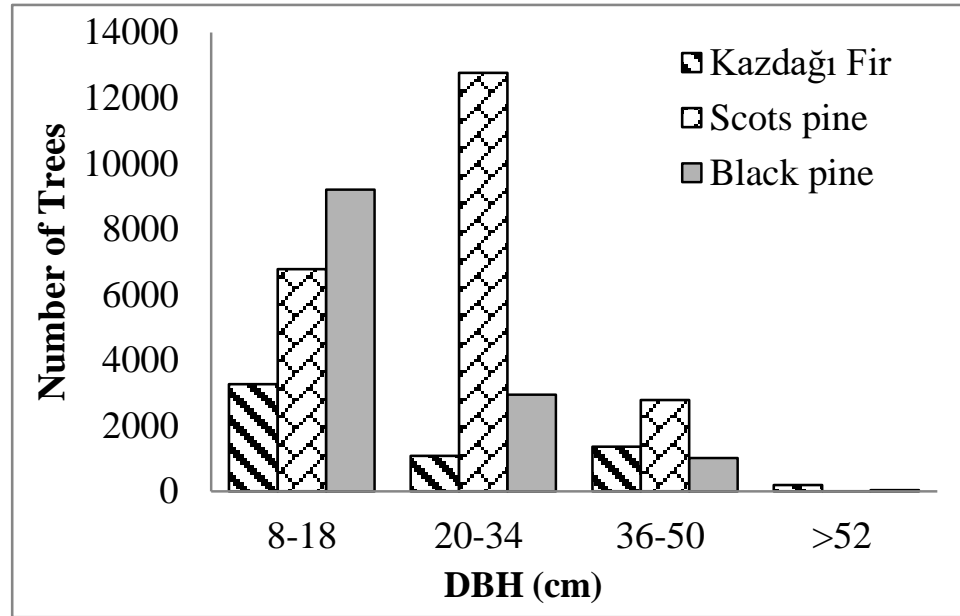

a)

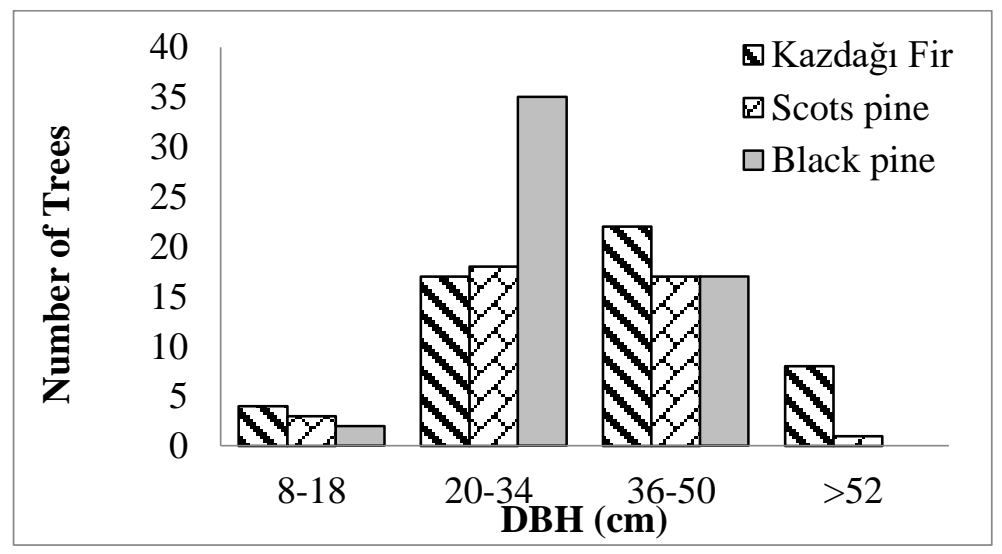

b)

Figure 3. Number and mean diameter classes at breast height (dbh) of damaged tree species (a) and nondamaged (control) tree species (b)

\section{Soil Properties}

Mean soil physical and chemical properties of the study sites are shown in Tables 2 and 3 . There were significant $(\mathrm{p}<0.001)$ differences in the soil physical and chemical properties among the three tree species, and between the windthrow and the control sites. Mean bulk density, sand content and pore volume were higher in the windthrow sites, whereas silt, clay and water holding capacity were lower in the windthrow sites (Table 2).

Among the control sites, Scots pine stands had the lowest soil bulk density $\left(0.672 \mathrm{~g} \mathrm{~cm}^{-}\right.$ ${ }^{3}$ ), percent clay $(9 \%)$ and maximum water holding capacity $(2.64 \%)$, whereas they had the highest percent sand (63\%), silt (28\%) and pore volume (39.48\%). Black pine stands showed the highest soil bulk density $(0.756 \mathrm{~g}$ $\left.\mathrm{cm}^{-3}\right)$ and the lowest percent silt (23\%) and pore volume $(35.98 \%)$. As for Kazdağ 1 fir stands, they had the lowest percent sand (58\%) and highest percent clay (18\%) and maximum water-holding capacity (20.66\%).

In contrary to the control sites, the windthrow sites, Scots pine stands showed the highest soil bulk density $\left(0.831 \mathrm{~g} \mathrm{~cm}^{-3}\right)$, but similarly, it showed the lowest percent clay $(9 \%)$. Black pine stands had the lowest percent sand $(66 \%)$ whereas they had the lowest pore volume $(37.66 \%)$ and maximum water-holding capacity (1.26\%). Kazdağ fir stands had the lowest soil bulk density $(0.742$ $\mathrm{g} \mathrm{cm}^{-3}$ ) and percent silt (17\%), while it had the highest percent sand (70\%), clay (13\%), 
pore volume $(47.8 \%)$ and maximum water holding capacity $(12.95 \%)$.

In the control sites, Kazdağ fir stands had the lowest soil $\mathrm{pH}$ (5.26) and concentrations of $\mathrm{Ca}\left(12.28 \mathrm{~g} \mathrm{~kg}^{-1}\right), \mathrm{Mg}\left(11.19 \mathrm{~g} \mathrm{~kg}^{-1}\right)$ and $\mathrm{Al}\left(105.02 \mathrm{~g} \mathrm{~kg}^{-1}\right)$ concentrations, whereas it had the highest soil organic carbon stock (27.69 Mg C ha $\left.{ }^{-1}\right)$, total nitrogen stock (1.62 $\left.\mathrm{Mg} \mathrm{N} \mathrm{ha}{ }^{-1}\right)$ and concentrations of $\mathrm{P}(0.64 \mathrm{~g}$ $\left.\mathrm{kg}^{-1}\right), \mathrm{K}\left(44.49 \mathrm{~g} \mathrm{~kg}^{-1}\right)$ and $\mathrm{S}\left(0.59 \mathrm{~g} \mathrm{~kg}^{-1}\right)$ concentrations. Scots pine stands showed the highest concentrations of $\mathrm{Ca}\left(42.36 \mathrm{~g} \mathrm{~kg}^{-1}\right)$, $\mathrm{Al}\left(85.89 \mathrm{~g} \mathrm{~kg}^{-1}\right)$ and lowest concentrations of $\mathrm{K}\left(5.50 \mathrm{~g} \mathrm{~kg}^{-1}\right)$ and $\mathrm{S}\left(0.24 \mathrm{~g} \mathrm{~kg}^{-1}\right)$. Black pine stands had the lowest soil organic carbon stock (22.69 $\left.\mathrm{Mg} \mathrm{C} \mathrm{ha}{ }^{-1}\right)$, total nitrogen stock $\left(0.96 \mathrm{Mg} \mathrm{N} \mathrm{ha}^{-1}\right)$ and $\mathrm{P}$ concentration $\left(0.38 \mathrm{~g} \mathrm{~kg}^{-1}\right)$ and highest $\mathrm{pH}$ (5.75) and $\mathrm{Mg}$ concentration (93.44 $\mathrm{g} \mathrm{kg}^{-1}$ ).

In the windthrow damaged sites, Kazdağ 1 fir sites showed the highest $\mathrm{pH}$ (5.94), SOC (34.73 $\mathrm{Mg} \mathrm{C}^{-1}$ ), TN stock (2.15 Mg N ha $\left.{ }^{1}\right)$ and concentrations of $\mathrm{P}\left(0.80 \mathrm{~g} \mathrm{~kg}^{-1}\right), \mathrm{K}$ $\left(27.18 \mathrm{~g} \mathrm{~kg}^{-1}\right)$ and $\mathrm{S}\left(0.84 \mathrm{~g} \mathrm{~kg}^{-1}\right)$, but it showed the lowest concentrations of $\mathrm{Mg}$
(10.16 $\left.\mathrm{g} \mathrm{kg}^{-1}\right)$ and $\mathrm{Al}\left(85.57 \mathrm{~g} \mathrm{~kg}^{-1}\right)$. Scots pine stands had the lowest $\mathrm{pH}$ (5.35) and $\mathrm{K}$ concentration $\left(4.86 \mathrm{~g} \mathrm{~kg}^{-1}\right)$, whereas it had the highest $\mathrm{Ca}$ concentration (37.19 $\left.\mathrm{g} \mathrm{kg}^{-1}\right)$. Black pine sites, however, had the lowest soil organic carbon stock (28.42 $\left.\mathrm{Mg} \mathrm{C} \mathrm{ha}^{-1}\right), \mathrm{TN}$ stock $\left(1.39 \mathrm{Mg} \mathrm{N} \mathrm{ha}^{-1}\right)$ and concentrations of $\mathrm{Ca}\left(11.99 \mathrm{~g} \mathrm{~kg}^{-1}\right), \mathrm{P}\left(0.43 \mathrm{~g} \mathrm{~kg}^{-1}\right)$ and $\mathrm{S}(0.17$ $\left.\mathrm{g} \mathrm{kg}^{-1}\right)$ while it had the highest concentrations of $\mathrm{Mg}\left(67.68 \mathrm{~g} \mathrm{~kg}^{-1}\right)$ and $\mathrm{Al}\left(91.85 \mathrm{~g} \mathrm{~kg}^{-1}\right)$ (Table 3).

The single effects and interactions of tree species and windthrow status on the soil properties are listed in Table 4. The main effects of tree species on organic carbon, nitrogen, total nitrogen stocks, $\mathrm{Ca}, \mathrm{Mg}, \mathrm{P}, \mathrm{K}$, $\mathrm{S}$ and $\mathrm{Al}$ concentrations were all significant $(\mathrm{P}<0.001)$, while the main effects of windthrow status were only significant for soil nitrogen content, $\mathrm{P}$ concentration, total nitrogen and soil organic carbon stocks $(\mathrm{P}<0.05)$. Tree species $\mathrm{x}$ windthrow status interaction was significant for the $\mathrm{pH}$ value, $\mathrm{Ca}, \mathrm{Mg}, \mathrm{K}$ and $\mathrm{Al}$ concentrations (Table 4).

Table 2. Mean soil physical characterics of three tree species from the control and windthrow sites

\begin{tabular}{|c|c|c|c|c|c|c|c|}
\hline $\begin{array}{l}\text { Soil properties } \\
\text { /variables }\end{array}$ & $\mathrm{N}$ & $\begin{array}{l}\text { Bulk density } \\
\qquad\left(\mathrm{g} \mathrm{cm}^{-3}\right)\end{array}$ & $\begin{array}{l}\text { Sand } \\
(\%)\end{array}$ & $\begin{array}{l}\text { Silt } \\
(\%)\end{array}$ & $\begin{array}{l}\text { Clay } \\
(\%)\end{array}$ & $\begin{array}{c}\text { Pore } \\
\text { Volume } \\
(\%)\end{array}$ & $\begin{array}{c}\text { Max. Water } \\
\text { Holding Capacity } \\
(\%)\end{array}$ \\
\hline & & Mean \pm SE & Mean \pm SE & Mean \pm SE & Mean \pm SE & Mean \pm SE & Mean \pm SE \\
\hline Kazdağ 1 Fir- ${ }^{-}$Control & 19 & $0.718^{\mathrm{ab}} \pm 0.018$ & $58^{\mathrm{a}} \pm 3.20$ & $24^{\mathrm{bc}} \pm 2.09$ & $18^{\mathrm{d}} \pm 1.31$ & $36.24^{\mathrm{a}} \pm 1.82$ & $20.66^{\mathrm{c}} \pm 2.06$ \\
\hline Scots pine- ${ }^{-}$Control & 12 & $0.672^{\mathrm{a}} \pm 0.040$ & $63^{\mathrm{b}} \pm 2.79$ & $28^{\mathrm{c}} \pm 2.12$ & $9^{\mathrm{a}} \pm 1.52$ & $39.48^{\mathrm{a}} \pm 0.77$ & $2.64^{\mathrm{a}} \pm 0.39$ \\
\hline Black pine- ${ }^{-}$ontrol & 21 & $0.756^{\mathrm{bc}} \pm 0.025$ & $62^{\mathrm{ab}} \pm 1.18$ & $23^{\mathrm{b}} \pm 1.32$ & $15^{\mathrm{c}} \pm 1.06$ & $35.98^{\mathrm{a}} \pm 1.27$ & $4.17^{\mathrm{a}} \pm 2.35$ \\
\hline Kazdağı Fir-windthrow & 33 & $0.742^{\mathrm{b}} \pm 0.014$ & $70^{c} \pm 1.55$ & $17^{\mathrm{a}} \pm 1.33$ & $13^{\mathrm{bc}} \pm 0.79$ & $47.86^{\mathrm{b}} \pm 1.42$ & $12.95^{\mathrm{b}} \pm 1.75$ \\
\hline Scots pine- Windthrow & 21 & $0.831^{\mathrm{d}} \pm 0.025$ & $70^{\mathrm{c}} \pm 1.44$ & $21^{\mathrm{b}} \pm 1.47$ & $9^{\mathrm{a}} \pm 0.98$ & $39.50^{\mathrm{a}} \pm 0.91$ & $2.03^{\mathrm{a}} \pm 0.48$ \\
\hline Black pine- Windthrow & 30 & $0.811^{\mathrm{cd}} \pm 0.021$ & $66^{\mathrm{bc}} \pm 0.75$ & $24^{\mathrm{bc}} \pm 0.91$ & $10^{\mathrm{ab}} \pm 0.73$ & $37.66^{\mathrm{a}} \pm 0.88$ & $1.26^{\mathrm{a}} \pm 0.11$ \\
\hline $\mathrm{F}$ & \multirow{2}{*}{136} & 5.739 & 6.860 & 5.509 & 11.768 & 14.601 & 24.002 \\
\hline Sig. & & $\mathrm{P}<0.001$ & $\mathrm{P}<0.001$ & $\mathrm{P}<0.001$ & $\mathrm{P}<0.001$ & $\mathrm{P}<0.001$ & $\mathrm{P}<0.001$ \\
\hline
\end{tabular}

Values indicate the range or the mean \pm standard error $(\mathrm{SE}) .{ }^{*}$ Where letters in superscript differ, data are significantly different $(\mathrm{p}<0.001), \mathrm{F}=$ variation between sample means/variation within the sample 
Table 3. Mean soil chemical characterics of three tree species from the control and windthrow sites

\begin{tabular}{|c|c|c|c|c|c|c|c|c|c|c|}
\hline Soil & & $\mathrm{pH}$ & $\begin{array}{c}\mathrm{SOC} \\
\mathrm{Mg} \mathrm{C} \mathrm{ha}^{-1}\end{array}$ & $\begin{array}{c}\mathrm{TN} \\
\mathrm{Mg} \mathrm{N} \mathrm{ha}^{-1}\end{array}$ & $\underset{\mathrm{g} \mathrm{kg}^{-1}}{\mathrm{Ca}}$ & $\underset{\mathrm{g} \mathrm{kg}^{-1}}{\mathrm{Mg}}$ & $\begin{array}{c}\mathrm{P} \\
\mathrm{g} \mathrm{kg}^{-1}\end{array}$ & $\underset{\mathrm{g} \mathrm{kg}^{-1}}{\mathrm{~K}}$ & $\underset{\mathrm{g} \mathrm{kg}^{-1}}{\mathrm{~S}}$ & $\begin{array}{c}\mathrm{Al} \\
\mathrm{g} \mathrm{kg}^{-1}\end{array}$ \\
\hline variables & 11 & $\begin{array}{l}\text { Mean } \\
\pm \text { SE }\end{array}$ & $\begin{array}{l}\text { Mean } \\
\pm \text { SE }\end{array}$ & $\begin{array}{l}\text { Mean } \\
\pm \text { SE }\end{array}$ & $\begin{array}{l}\text { Mean } \\
\pm \text { SE }\end{array}$ & $\begin{array}{l}\text { Mean } \\
\pm \text { SE }\end{array}$ & $\begin{array}{l}\text { Mean } \\
\pm \text { SE }\end{array}$ & $\begin{array}{l}\text { Mean } \\
\pm \text { SE }\end{array}$ & $\begin{array}{l}\text { Mean } \\
\pm \text { SE }\end{array}$ & $\begin{array}{l}\text { Mean } \\
\pm \text { SE }\end{array}$ \\
\hline $\begin{array}{c}\text { Kazdağı Fir- } \\
\text { Control }\end{array}$ & 19 & $5.26^{\mathrm{a}} \pm 0.086$ & $27.69^{\mathrm{abc}} \pm 2.34$ & $1.62^{\mathrm{bc}} \pm 0.17$ & $12.28^{\mathrm{a}} \pm 2.831$ & $11.19^{\mathrm{a}} \pm 0.616$ & $0.64^{\mathrm{bc}} \pm 0.090$ & $44.49^{\mathrm{d}} \pm 4.587$ & $0.59^{\mathrm{cd}} \pm 0.214$ & $105.02^{\mathrm{c}} \pm 6.840$ \\
\hline $\begin{array}{l}\text { Scots pine- } \\
\text { Control }\end{array}$ & 12 & $5.60^{\mathrm{abc}} \pm 0.162$ & $26.44^{\mathrm{ab}} \pm 2.61$ & $1.46^{\mathrm{bc}} \pm 0.17$ & $42.36^{c} \pm 3.187$ & $33.90^{\mathrm{b}} \pm 1.834$ & $0.61^{\mathrm{b}} \pm 0.043$ & $5.50^{\mathrm{a}} \pm 1.558$ & $0.24^{\mathrm{a}} \pm 0.038$ & $85.89^{\mathrm{b}} \pm 2.996$ \\
\hline $\begin{array}{l}\text { Black pine- } \\
\text { Control }\end{array}$ & 21 & $5.75^{\mathfrak{c}} \pm 0.086$ & $22.69^{\mathrm{a}} \pm 3.23$ & $0.96^{\mathrm{a}} \pm 0.10$ & $20.19^{\mathrm{b}} \pm 2.781$ & $93.44^{\mathrm{d}} \pm 12.261$ & $0.38^{\mathrm{a}} \pm 0.053$ & $7.67^{\mathrm{a}} \pm 1.176$ & $0.27^{\mathrm{ab}} \pm 0.0686$ & $62.51^{\mathrm{a}} \pm 6.738$ \\
\hline $\begin{array}{l}\text { Kazdağı Fir- } \\
\text { Windthrow }\end{array}$ & 33 & $5.94^{\mathrm{c}} \pm 0.157$ & $34.73^{c} \pm 1.61$ & $2.15^{\mathrm{d}} \pm 0.12$ & $19.20^{\mathrm{ab}} \pm 2.287$ & $10.16^{\mathrm{a}} \pm 0.629$ & $0.80^{c} \pm 0.070$ & $27.18^{\mathrm{c}} \pm 3.081$ & $0.84^{\mathrm{d}} \pm 0.122$ & $85.57^{\mathrm{b}} \pm 4.372$ \\
\hline $\begin{array}{c}\text { Scots pine- } \\
\text { Windthrow }\end{array}$ & 21 & $5.35^{\mathrm{ab}} \pm 0.082$ & $31.41^{\mathrm{bc}} \pm 2.30$ & $1.83^{\mathrm{cd}} \pm 0.15$ & $37.19^{\mathrm{c}} \pm 3.348$ & $38.32^{\mathrm{b}} \pm 0.804$ & $0.76^{\mathrm{bc}} \pm 0.016$ & $4.86^{\mathrm{a}} \pm 0.387$ & $0.31^{\mathrm{ab}} \pm 0.028$ & $86.49^{\mathrm{b}} \pm 1.754$ \\
\hline $\begin{array}{l}\text { Black pine- } \\
\text { Windthrow }\end{array}$ & 30 & $5.67^{\mathrm{bc}} \pm 0.067$ & $28.42^{\mathrm{abc}} \pm 2.35$ & $1.39^{\mathrm{b}} \pm 0.08$ & $11.99^{\mathrm{a}} \pm 0.806$ & $67.68^{c} \pm 5.524$ & $0.43^{\mathrm{a}} \pm 0.016$ & $15.43^{\mathrm{b}} \pm 0.685$ & $0.17^{\mathrm{a}} \pm 0.0179$ & $91.85^{b c} \pm 3.066$ \\
\hline $\mathrm{F}$ & & 4.743 & 3.315 & 11.339 & 21.404 & 39.095 & 10.133 & 33.551 & 7.154 & 7.688 \\
\hline Sig. & & $\mathrm{P}<0.001$ & $\mathrm{P}<0.001$ & $\mathrm{P}<0.001$ & $\mathrm{P}<0.001$ & $\mathrm{P}<0.001$ & $\mathrm{P}<0.001$ & $\mathrm{P}<0.001$ & $\mathrm{P}<0.001$ & $\mathrm{P}<0.001$ \\
\hline
\end{tabular}

Values indicate the range or the mean \pm standard error (SE). ${ }^{*}$ Where letters in superscript differ, data are significantly different (p <0.001). SOC: Soil Organic Carbon, TN: Total Nitrogen, Ca: Calcium, Mg: Magnesium, P: Phosphorus, K: Potassium, S: Sulphur, Al: Aluminum 
Table 4. ANOVA of soil properties from the control and windthrow sites

\begin{tabular}{|c|c|c|c|c|c|c|}
\hline \multicolumn{2}{|c|}{$\begin{array}{c}\text { Soil properties/ Variables } \\
\text { source }\end{array}$} & Sum of Square & df & Mean of square & $F$-value & $P$-value \\
\hline \multirow{3}{*}{$\mathrm{pH}$} & $\mathrm{TS}$ & 1.014 & 2 & 0.507 & 1.573 & 0.211 \\
\hline & WS & 0.432 & 1 & 0.432 & 1.341 & 0.249 \\
\hline & TS x WS & 5.172 & 2 & 2.586 & 8.021 & 0.001 \\
\hline \multirow{3}{*}{$\begin{array}{c}\text { Organic } \\
\text { Carbon } \\
(\%)\end{array}$} & $\mathrm{TS}$ & 32.226 & 2 & 16.113 & 9.907 & 0.000 \\
\hline & WS & 5.796 & 1 & 5.796 & 3.563 & 0.061 \\
\hline & TS $x$ WS & 4.512 & 2 & 2.256 & 1.387 & 0.253 \\
\hline \multirow{3}{*}{$\begin{array}{l}\text { Nitrogen } \\
(\%)\end{array}$} & TS & 0.314 & 2 & 0.157 & 28.024 & 0.000 \\
\hline & WS & 0.054 & 1 & 0.054 & 9.582 & 0.002 \\
\hline & TS $x$ WS & 0.002 & 2 & 0.001 & 0.220 & 0.803 \\
\hline \multirow{3}{*}{$\begin{array}{c}\mathrm{TN} \\
\left(\mathrm{Mg} \mathrm{ha}^{-1}\right)\end{array}$} & $\mathrm{TS}$ & 12.636 & 2 & 6.318 & 17.001 & 0.000 \\
\hline & WS & 5.881 & 1 & 5.881 & 15.824 & 0.000 \\
\hline & TS x WS & 0.121 & 2 & 0.060 & 0.163 & 0.850 \\
\hline \multirow{3}{*}{$\begin{array}{c}\mathrm{SOC} \\
\left(\mathrm{Mg} \mathrm{ha}^{-1}\right)\end{array}$} & TS & 787.560 & 2 & 393.780 & 3.030 & 0.052 \\
\hline & WS & 1068.755 & 1 & 1068.755 & 8.222 & 0.005 \\
\hline & TS x WS & 21.808 & 2 & 10.904 & 0.084 & 0.920 \\
\hline \multirow{3}{*}{$\begin{array}{c}\mathrm{Ca} \\
\left(\mathrm{g} \mathrm{kg}^{-1}\right)\end{array}$} & $\mathrm{TS}$ & 13242.969 & 2 & 6621.485 & 47.475 & 0.000 \\
\hline & WS & 141.094 & 1 & 141.094 & 1.012 & 0.316 \\
\hline & TS $x$ WS & 1509.825 & 2 & 754.913 & 5.413 & 0.006 \\
\hline \multirow{3}{*}{$\begin{array}{c}\mathrm{Mg} \\
\left(\mathrm{g} \mathrm{kg}^{-1}\right)\end{array}$} & $\mathrm{TS}$ & 128896.999 & 2 & 64448.499 & 92.109 & 0.000 \\
\hline & WS & 2360.091 & 1 & 2360.091 & 3.373 & 0.069 \\
\hline & TS $x$ WS & 7359.845 & 2 & 3679.922 & 5.259 & 0.006 \\
\hline \multirow{3}{*}{$\begin{array}{c}\mathrm{P} \\
\left(\mathrm{g} \mathrm{kg}^{-1}\right)\end{array}$} & $\mathrm{TS}$ & 2.786 & 2 & 1.393 & 18.761 & 0.000 \\
\hline & WS & 0.463 & 1 & 0.463 & 6.236 & 0.014 \\
\hline & TS $x$ WS & 0.074 & 2 & 0.037 & 0.497 & 0.609 \\
\hline \multirow{3}{*}{$\begin{array}{c}\mathrm{K} \\
\left(\mathrm{g} \mathrm{kg}^{-1}\right)\end{array}$} & TS & 22242.967 & 2 & 11121.483 & 77.738 & 0.000 \\
\hline & WS & 353.027 & 1 & 353.027 & 2.468 & 0.119 \\
\hline & TS $x$ WS & 3928.098 & 2 & 1964.049 & 13.728 & 0.000 \\
\hline \multirow{3}{*}{$\begin{array}{c}\mathrm{S} \\
\left(\mathrm{g} \mathrm{kg}^{-1}\right)\end{array}$} & $\mathrm{TS}$ & 6.984 & 2 & 3.492 & 13.168 & 0.000 \\
\hline & WS & 0.158 & 1 & 0.158 & 0.597 & 0.441 \\
\hline & TS $x$ WS & 0.737 & 2 & 0.368 & 1.389 & 0.253 \\
\hline \multirow{3}{*}{$\begin{array}{c}\mathrm{Al} \\
\left(\mathrm{g} \mathrm{kg}^{-1}\right)\end{array}$} & $\mathrm{TS}$ & 6869.151 & 2 & 3434.575 & 7.475 & 0.001 \\
\hline & WS & 205.635 & 1 & 205.635 & 0.448 & 0.505 \\
\hline & TS $x$ WS & 13017.676 & 2 & 6508.838 & 14.166 & 0.000 \\
\hline
\end{tabular}

SOC: Soil Organic Carbon, TN: Total Nitrogen, Ca: Calcium, Mg: Magnesium, P: Phosphorus, K: Potassium, S: Sulphur, Al: Aluminum Tree species (TS), Windthrow status (WS)

\section{Discussion}

Effects of Wind Speed on Windthrow

Windthrown damage to forest trees is quite high due to a certain speed of wind blowing. Coutts (1986) showed that only 13 $\mathrm{m} \mathrm{s}^{-1}$ and $18 \mathrm{~m} \mathrm{~s}^{-1}$ canopy top wind velocity was enough to uproot Sitka spruce and Scots pine, respectively. Other researchers, however, reported critical wind speeds as over $20 \mathrm{~m} \mathrm{~s}^{-1}$ (Fraser \& Gardiner, 1967). A survey in pine forests in East Anglia recorded wind speed of $17.5 \mathrm{~m} \mathrm{~s}^{-1}$ at treetop causing uprooting (Oliver \& Mayhead, 1974). Canham et al. (2001) have argued that variation in damage severity is both a widespread and ecologically critical feature of wind damage in forests. In our study, the windthrow with an average wind speed of $22.5 \mathrm{~m} \mathrm{~s}^{-1}$ in March 2013 caused significant tree damage in the studied sites. According to annual wind rose graphs, mean wind speeds in the area are generally between $19 \mathrm{~m} \mathrm{~s}^{-1}$ 
and $26 \mathrm{~m} \mathrm{~s}^{-1}$, and it increases during spring season. According to the monthly basis climate parameters of the meteorology station in the region, it could be possible to say that an increase in temperature and wind speed and heavy rainfall in the region may be the effective factors to overturned trees in the study sites.

\section{Variation in Soil Properties after Windthrow}

The results show that windthrow in the study sites has a serious and long-term effect on the soil properties. For the three tree species, soil bulk density was generally low in the control sites (Table 2). Lang et al. (2009) also reported for windthrow salvaged and unsalvaged areas on the Flambeau River State Forest in the USA that bulk density ranged from 1.77 to $2.07 \mathrm{~g} \mathrm{~cm}^{-3}$ in the windthrow salvaged areas, while bulk density in the control areas ranged from 1.66 to 1.86 $\mathrm{g} \mathrm{cm}^{-3}$. Kooch (2007) found that soil bulk density negatively correlated with soil clay content and positively correlated with soil sand content. In our results, there was a negative correlation between the soil bulk density and the clay content $(\mathrm{p}=0.003, \mathrm{r}=-$ $0.254, n=136$ ). The soil bulk density tended to decrease in clay soils compared to sandy soils. It seemed that the greater amount of clay in the control sites resulted in a reduction in soil bulk density, while windthrow sites had higher soil bulk density due to the aggregation of the sand components. In our study, we noted that soil bulk density generally increased more around mature overturned trees due to their weights. Some studies showed that soils were more compacted in deeper layers due to increased bulk density (Kooch et al., 2012). Moreover, the removal of overturned trees from sites by forest machinery can increase soil bulk density.

The damaged and non-damaged areas showed similar soil type, pore volume and texture in shallower soil horizons (Table 2). Similar results were reported by Don et al. (2012) who found that soil type, texture and nutrients were similar in the damaged and non-damaged sites under Picea abies with an admixture of Larix decidua and Pinus sylvestris. Mayer et al. (2005) reported for the damaged sites in France that soil texture was coarse (sandy) grained. High variation in soil-water content on the wind-damaged sites could be related to soil depth due to high percolation through shallow soils with high stone content (e.g. Leptosols). More than five years after windthrow, we did not observe any significant difference in maximum water holding capacity between Scots pine and Black pine stands. Similarly, other studies also did not find any differences in field water content between the windthrow and no intervention sites (Šimkovic et al., 2009; Gáfriková et al., 2019). However, we observed some differences in maximum water holding capacity between the windthrow and the control sites for Kazdağ fir (Table 2). This may be since the Kazdağ fir is considered as a shadow tree and soil water holding capacity decreases due to gaps in the fir stand after windthrow.

The soil types in the study subplots was very similar (Rendzic Leptosol). In general, the windthrow sites with low $\mathrm{pH}$ (except for Kazdağı fir) were correlated with shallow, coarse soil and high soil bulk density. In addition, we noted for all tree species that there was a difference in soil $\mathrm{pH}$ between the windthrow and the control sites (Table 4). Nitrogen and sulphur depositions are known to cause soil acidification on poorly buffered soils, and the forest stands with acidic soils are more severely damaged (Wild, 1993). Gömöryová et al. (2008) found in the Tatra National Park that mean soil $\mathrm{pH}$ in reference sites was 4.07, while at the sites after disturbances, it was 4.26 and 4.34 in spruce and larch stands, respectively. In contrary, Mayer et al. (2005) showed that greater storm damage resulted in lower soil $\mathrm{pH}$. They argued that the significative factor for soil $\mathrm{pH}$ was bedrock, or more precisely, the carbonate content and buffer capacity of the bedrock.

Total soil organic carbon stocks after windthrow showed an increase for all three species compared to the control sites (Tables 3 and 4). Santos et al. (2016) also reported that soil organic carbon stocks in the disturbed plots were higher than in the undisturbed plots. Similar results were also found by several researchers (Mattson \& Swank, 1989; Hendrickson et al., 1989). In contrary, Kramer et al. (2004) showed that 
soil organic carbon stocks decreased from $216 \mathrm{Mg} \mathrm{C} \mathrm{ha}^{-1}$ in the least disturbed to 157 $\mathrm{Mg} \mathrm{C} \mathrm{ha}{ }^{-1}$ in the most disturbed forests in southeast Alaska. On the other hand, clear cuts due to the windthrow might cause soil organic carbon losses in the organic horizon (Covington, 1981; Brais et al., 1995; Kramer et al., 2004; Pang et al., 2011). Soil organic carbon stocks could be also affected by other factors such as mineral compounds, soil type, and soil texture (Powers \& Veldkamp, 2005; López-Ulloa et al., 2005; Neumann-Cosel et al., 2011). Higher values in SOC stocks in the disturbed sites may be also related to geology and partially decomposed organic debris after overturning (Quesada et al., 2010). Soil organic matter amounts can be strongly influenced by windthrow (Kramer et al., 2001), which can recycle and mix mineral and organic soil horizons to bedrock. Changes in SOC values in different soils may affect other important factors such as climate characteristics, geology and soil formation (Adams et al., 1990; Batjes, 1996). We also found differences in total nitrogen stocks under all tree species between the windthrow and the control sites (Table 4). Total nitrogen stocks were higher in the windthrow than in the control sites (Table 3). The main reason for this increase in the windthrow sites could be attributed to tree removal after the overturning, the change of microclimate conditions, the rapid litter decomposition depending on the litter quantity and quality from regrowing trees and newly sprouting vegetation.

In our study, $\mathrm{Ca}, \mathrm{Mg}, \mathrm{K}$ and $\mathrm{Al}$ concentrations significantly varied between three tree species (TS) and windthrow status $x$ tree species (WS $x$ TS) while $S$ concentration varied only with three tree species (Table 4). Increased soil nutrients after the windthrows in our study could be related to better environmental conditions created by the pit mounds. Windthrow often causes uprooting of trees which expose and invert mineral soils at the forest floor (Pawlik, 2013). Mounds and pits following windthrow are shown to increase soil features such as available nutrients and biomass of earthworms (Kooch et al., 2015). The amounts of nutrients lost can vary catastrophic depending on the severity and duration of the disturbance and the forest type (Kozlowski \& Pallardy, 1997).

\section{Conclusion}

Our study has shown that severe wind damage can occur when mean wind speeds exceed $22.5 \mathrm{~m} \mathrm{~s}^{-1}$. However, the relationship between damage and wind speeds is difficult to study. Our results also indicate that wind damage increases during the spring season. According to the climate parameters of the meteorology station in the region, it may be said that an increase in temperature and wind speed and heavy rainfall in the region may be the most effective factors to overturned trees in the study sites. The forest road direction within or adjacent to the Scots pine and black pine stands in the study sites may also accelerate the effects of wind speed, especially when the forest roads are opened parallel to the dominant wind direction which significantly increases the turbulence.

Our results show that windthrow should be considered as an important factor influencing forest ecosystem. There are significant $(\mathrm{p}<0.001)$ differences in physical and chemical properties of soil between tree species and windthrow status. Our results showed that soil organic carbon, bulk density, sand content, pore-volume, total nitrogen, phosphorus and sulphur (except for Scots pine) concentrations are much higher in the windthrow sites than in the control sites. Most of these variations are probably due to a perturbation of soil horizon during windthrow. More detailed studies are experimentally in need to investigate the relationships between chemical properties of soil and root growth/morphology.

\section{Acknowledgments}

We are thankful to Kastamonu Regional Forest Directorate for giving permission to collect the soil data in the forest sites and to Kastamonu Meteorology Station Directorate for providing us the scientific meteorological data.

\section{Ethics Committee Approval N/A}




\section{Peer-review}

Externally peer-reviewed.

\section{Author Contributions}

Conceptualization:

G.S., $\quad$ T.S.;

Investigation: G.S., T.S., S.Ç, F.K., E.T.; Material and Methodology: G.S., T.S., S.Ç, F.K., E.T.; Supervision: G.S., T.S.; Visualization: G.S., T.S.; Writing-Original Draft: G.S., T.S.; Writing-review \& Editing: G.S., T.S., S.Ç., F.K.; Other: All authors have read and agreed to the published version of manuscript.

\section{Conflict of Interest}

The authors have no conflicts of interest to declare.

\section{Funding}

This research has been supported by the Kastamonu University, Scientific Research Projects Coordination Department (KUBAP) Kastamonu, Turkey (Project Number: KUBAP 01/2018-22).

\section{References}

Adams, J. M., Faure, H. F. D. L., Faure-Denard, L., McGlade, J. M. \& Woodward, F. I. (1990). Increases in terrestrial carbon storage from the Last Glacial Maximum to the present. Nature, 348(6303), 711-714.

Akbaş, B., Akdeniz, N., Aksay, A., Altun, İ.E., Balc1, V., Bilginer, E., Bilgiç, T., Duru, M., Ercan, T., Gedik, İ., Günay, Y., Güven, İ.H., Hakyemez, H.Y., Konak, N., Papak, İ., Pehlivan, Ş., Sevin, M., Şenel, M., Tarhan, N., Turhan, N., Türkecan, A., Ulu, Ü., Uğuz, M.F., Yurtsever, A. ve diğerleri, 2011, 1:1.250.000 ölçekli Türkiye Jeoloji Haritası. Maden Tetkik ve Arama Genel Müdürlüğü Yayını, Ankara-Türkiye.

Allen, S. E. (1989). Chemical analysis of ecological materials. Blackwell, Oxford.

Batjes, N. H. (1996). Total carbon and nitrogen in the soils of the world. European Journal of Soil Science, 47(2), 151-163.

Beatty, S. W. \& Stone, E. L. (1986). The variety of soil microsites created by tree falls. Canadian Journal of Forest Research, 16(3), 539-548.

Blake, G. R. \& Hartge, K. H. (1986). Bulk density 1. Methods of soil analysis: part 1physical and mineralogical methods, (methodsofsoilan1), 363-375.
Bouget, C. \& Duelli, P. (2004). The effects of windthrow on forest insect communities: a literature review. Biological Conservation, 118(3), 281-299.

Bouyoucos, G. J. (1962). Hydrometer method improved for making particle size analyses of soils 1. Agronomy Journal, 54(5), 464-465.

Brais, S., Camiré, C. \& Paré, D. (1995). Impacts of whole-tree harvesting and winter windrowing on soil $\mathrm{pH}$ and base status of clayey sites of northwestern Quebec. Canadian Journal of Forest Research, 25(6), 997-1007.

Canham, C. D., Papaik, M. J. \& Latty, E. F. (2001). Interspecific variation in susceptibility to windthrow as a function of tree size and storm severity for northern temperate tree species. Canadian Journal of Forest Research, 31(1), 1-10.

Coutts, M. P. (1986). Components of tree stability in Sitka spruce on peaty gley soil. Forestry: An International Journal of Forest Research, 59(2), 173-197.

Covington, W. W. (1981). Changes in forest floor organic matter and nutrient content following clear cutting in northern hardwoods. Ecology, 62(1), 41-48.

Don, A., Bärwolff, M., Kalbitz, K., Andruschkewitsch, R., Jungkunst, H. F. \& Schulze, E. D. (2012). No rapid soil carbon loss after a windthrow event in the High Tatra. Forest Ecology and Management, 276, 239246.

Engür, M. O. (2010). Rüzgar devriği hasarlarinda durum değerlendirmesi ve odun üretimi. III. Ulusal Karadeniz Ormancılık Kongresi 20-22 May1s 2010, Cilt: III Sayfa: 905-914

Engür, M. O. (2014). Odun Üretiminde Çalışanların eğitimi, Ağaç Kesme ve Boylama Operatörü. TC Orman ve Su İşleri Bakanlığ1, Orman Genel Müdürlüğü.

ESBN (European Soil Bureau Network European Commission) (2005). Soil Atlas of Europe. 128 pp Office for Official Publications of the European Communities, L-2995 Luxembourg.

Fraser, A. I. \& Gardiner, J. B. H. (1967). Rooting and stability in Sitka spruce (No. 40). London: HM Stationery Office.

Gáfriková, J., Hanajík, P., Vykouková, I., Zvarík, M., Ferianc, P., Drahovská, H. \& Puškárová, A. (2019). Dystric Cambisol properties at windthrow sites with secondary succession developed after 12 years under different conditions in Tatra National Park. Biologia, 74(9), 1099-1114.

Gáfriková, J., Zvarík, M., Hanajík, P., Súlovský, M. \& Vykouková, I. (2020). Impact of natural disturbance, forest management and 
vegetation cover on topsoil biochemical characteristics of Tatra Mts.(Slovakia). Journal of Mountain Science, 17, 1294-1309.

Gardiner, B., Blennow, K., Carnus, J. M., Fleischer, P., Ingemarsson, F., Landmann, G. \& Peyron, J. L. (2010). Destructive storms in European forests: past and forthcoming impacts. EFIATLANTIC, European Forest Institute, Cestas, France.

Gömöryová, E., Střelcová, K., Škvarrnina, J., Bebej, J. \& Gömöry, D. (2008). The impact of windthrow and fire disturbances on selected soil properties in the Tatra National Park. Soil and Water Research, 3(Special Issue No. 1), S74-S80.

Hartmann, A., Kobler, J., Kralik, M., Dirnböck, T., Humer, F. \& Weiler, M. (2016). Modelaided quantification of dissolved carbon and nitrogen release after windthrow disturbance in an Austrian karst system. Biogeosciences, 13(1), 159-174.

Hendrickson, O. Q., Chatarpaul, L. \& Burgess, D. (1989). Nutrient cycling following whole-tree and conventional harvest in northern mixed forest. Canadian Journal of Forest Research, 19(6), 725-735.

Jackson, M. L. (1962). Soil chemical analysis. (Constable and Company, Ltd: London).

Karaöz, M. Ö. (1989). Toprakların su ekonomisine ilişkin bazı fiziksel özelliklerinin laboratuvarda belirlenmesi yöntemleri. İstanbul Üniversitesi Orman Fakültesi Dergisi, 39(2), 133-144.

Klaus, M., Holsten, A., Hostert, P. \& Kropp, J. P. (2011). Integrated methodology to assess windthrow impacts on forest stands under climate change. Forest Ecology and Management, 261(11), 1799-1810.

Kooch, Y. (2007). Determination and differentiation of ecosystem units in relation to soil properties in Khanilan forests (Doctoral dissertation, M.Sc. thesis of Forestry). Persian: Publication of Mazandaran University), 130.

Kooch, Y., Darabi, S. M. \& Hosseini, S. M. (2015). Effects of pits and mounds following windthrow events on soil features and greenhouse gas fluxes in a temperate forest. Pedosphere, 25(6), 853-867.

Kooch, Y., Hosseini, S. M., Zaccone, C., Jalilvand, H. \& Hojjati, S. M. (2012). Soil organic carbon sequestration as affected by afforestation: the Darab Kola forest (North of Iran) case study. Journal of Environmental Monitoring, 14(9), 2438-2446.

Kozlowski, T. T. \& Pallardy, S. G. (1997). Chapter 10 - Mineral Nutrition, Editor(s): Theodore T. Kozlowski, Stephen G. Pallardy,
Physiology of Woody Plants (Second Edition), Academic Press, 210-236.

Kramer, M. G., Hansen, A. J., Taper, M. L. \& Kissinger, E. J. (2001). Abiotic controls on long-term windthrow disturbance and temperate rain forest dynamics in southeast Alaska. Ecology, 82(10), 2749-2768.

Kramer, M. G., Sollins, P. \& Sletten, R. S. (2004). Soil carbon dynamics across a windthrow disturbance sequence in southeast Alaska. Ecology, 85(8), 2230-2244.

Lang, K. D., Schulte, L. A. \& Guntenspergen, G. R. (2009). Windthrow and salvage logging in an old-growth hemlock-northern hardwoods forest. Forest Ecology and Management, 259(1), 56-64.

Lee, J., Hopmans, J. W., Rolston, D. E., Baer, S. G. \& Six, J. (2009). Determining soil carbon stock changes: simple bulk density corrections fail. Agriculture, Ecosystems \& Environment, 134(3-4), 251256 https://doi.org/10.1016/j.agee.2009.07.006

Lohmander, P. \& Helles, F. (1987). Windthrow probability as a function of stand characteristics and shelter. Scandinavian Journal of Forest Research, 2(1-4), 227-238.

López-Ulloa, M., Veldkamp, E. \& De Koning, G. H. J. (2005). Soil carbon stabilization in converted tropical pastures and forests depends on soil type. Soil Science Society of America Journal, 69(4), 1110-1117.

Majunke, C., Matz, S. \& Müller, M. (2008). Sturmschäden in Deutschlands Wäldern von 1920 bis 2007. AFZ-Der Wald, 63, 380-381.

Mason, B. \& Valinger, E. (2013). Managing forests to reduce storm damage. Chapter $4 \mathrm{~b}$. Gardiner B, Schuck A, Schelhaas MJ, Orazio C, Blennow K, Nicoll B, editors.

Mattson, K. G. \& Swank, W. T. (1989). Soil and detrital carbon dynamics following forest cutting in the Southern Appalachians. Biology and Fertility of Soils, 7(3), 247-253.

Mayer, P., Brang, P., Dobbertin, M., Hallenbarter, D., Renaud, J. P., Walthert, L. \& Zimmermann, S. (2005). Forest storm damage is more frequent on acidic soils. Annals of Forest Science, 62(4), 303-311.

Mina, M., Bugmann, H., Cordonnier, T., Irauschek, F., Klopcic, M., Pardos, M. \& Cailleret, M. (2017). Future ecosystem services from European mountain forests under climate change. Journal of Applied Ecology, 54(2), 389-401.

Neumann-Cosel, L., Zimmermann, B., Hall, J. S., van Breugel, M. \& Elsenbeer, H. (2011). Soil carbon dynamics under young tropical secondary forests on former pastures - A case 
study from Panama. Forest Ecology and Management, 261(10), 1625-1633.

Oliver, H. R. \& Mayhead, G. J. (1974). Wind measurements in a pine forest during a destructive gale. Forestry: An International Journal of Forest Research, 47(2), 185-194.

Özyuvac1, N. (1975). Topraklarda Erozyon Eğiliminin Tahmini Açısından Yapılan Bazı Değerlendirmeler. TÜBİTAK V. Bilim Kongresi, Tarım ve Ormancılık Araştırma Grubu Tebliğleri Ormancilık Seksiyonu, 29 Eylül-2 Ekim, 123-134. İzmir.

Pang, X. Y., Bao, W. K. \& Wu, N. (2011). The effects of clear-felling subalpine coniferous forests on soil physical and chemical properties in the eastern Tibetan Plateau. Soil Use and Management, 27(2), 213-220.

Pawlik, Ł. (2013). The role of trees in the geomorphic system of forested hillslopes-a review. Earth-Science Reviews, 126, 250-265.

Pischedda, D. (2004). Technical guide on harvesting and conservation of storm damaged timber. Paris: CTBA

Powers, J. S. \& Veldkamp, E. (2005). Regional variation in soil carbon and $\delta 13 \mathrm{C}$ in forests and pastures of northeastern Costa Rica. Biogeochemistry, 72(3), 315-336.

Quesada, C. A., Lloyd, J., Schwarz, M., Patiño, S., Baker, T. R., Czimczik, C. \& Santos, A. J. B. (2010). Variations in chemical and physical properties of Amazon forest soils in relation to their genesis. Biogeosciences, 7(5), 15151541.

Quine, C. P. (1995a). Forests and wind: management to minimize damage. HMSO For Comm Bull, 114.

Quine, C. P. (1995b). Assessing the risk of wind damage to forests: practice and pitfalls. Wind and trees, 379-403, in M. P. Coutts and J. Grace, editors. Wind and trees. Cambridge University Press, Cambridge, UK.

Riguelle, S. (2016). Dealing with storm impacts on the forest sector through integrated and systemic approaches at the regional level (Doctoral dissertation, Université de Liège, Gembloux, Belgique.

Santos, L. T. D., Magnabosco Marra, D., Trumbore, S., Camargo, P. B. D., NegrónJuárez, R. I., Lima, A. J. \& Higuchi, N.
(2016). Windthrows increase soil carbon stocks in a central Amazon forest. Biogeosciences, 13(4), 1299-1308.

Sariyildiz, T., Savaci, G. \& Kravkaz, I. S. (2015). Effects of tree species, stand age and land-use change on soil carbon and nitrogen stock rates in northwestern Turkey. iForestBiogeosciences and Forestry, 9(1), 165. https://doi.org/10.3832/ifor1567-008

Schaetzl, R. J., Burns, S. F., Johnson, D. L. \& Small, T. W. (1989). Tree uprooting: review of impacts on forest ecology. Vegetatio, 79(3), 165-176.

Šimkovic, I., Dlapa, P., Šimonovicová, A. \& Ziegler, W. (2009). Water Repellency of Mountain Forest Soils in Relation to Impact of the Katabatic Windstorm and Subsequent Management Practices. Polish Journal of Environmental Studies, 18(3).

Solantie, R. (1994). Effect of weather and climatological background on snow damage of forests in southern Finland in November 1991. Silva Fenn. 28(3), 203-211.

Sommerfeld, A., Senf, C., Buma, B., D’Amato, A. W., Després, T., Díaz-Hormazábal, I. \& Seidl, R. (2018). Patterns and drivers of recent disturbances across the temperate forest biome. Nature Communications, 9(1), 1-9.

Stephens, E. P. (1956). The uprooting of trees: a forest process. Soil Science Society of America Journal, 20(1), 113-116.

von Oheimb, G., Friedel, A., Bertsch, A. \& Härdtle, W. (2007). The effects of windthrow on plant species richness in a Central European beech forest. Plant Ecology, 191(1), 47-65.

Wild, A. (1993). Soils and the Environment. Cambridge University Press. 